Research Article

\title{
Ancestral association between HLA and HFE H63D and C282Y gene mutations from northwest Colombia
}

\author{
Libia M Rodriguez ${ }^{1}$, Mabel C Giraldo ${ }^{1}$, Laura I Velasquez ${ }^{1}$, Cristiam M Alvarez ${ }^{1}$, Luis F Garcia ${ }^{1}$, \\ Marlene Jimenez-Del-Rio ${ }^{2}$ and Carlos Velez-Pardo ${ }^{2}$ \\ ${ }^{1}$ Grupo Inmunología Celular e Inmunogenética, Instituto de Investigaciones Médicas, \\ Facultad de Medicina, Universidad de Antioquia, Medellín, Colombia. \\ ${ }^{2}$ Grupo de Neurociencias, Instituto de Investigaciones Médicas, Facultad de Medicina, \\ Universidad de Antioquia, Medellín, Colombia.
}

\begin{abstract}
A significant association between HFE gene mutations and the HLA-A*03-B*07 and HLA-A*29-B*44 haplotypes has been reported in the Spanish population. It has been proposed that these mutations are probably connected with Celtic and North African ancestry, respectively. We aimed to find the possible ancestral association between HLA alleles and haplotypes associated with the HFE gene (C282Y and H63D) mutations in 214 subjects from Antioquia, Colombia. These were 18 individuals with presumed hereditary hemochromatosis ("HH") and 196 controls. The $\mathrm{HLA} \mathrm{B}^{\star} 07$ allele was in linkage disequilibrium (LD) with $\mathrm{C} 282 \mathrm{Y}$, while $\mathrm{HLA}-\mathrm{A}^{\star} 23, \mathrm{~A}^{\star} 29, \mathrm{HLA}-\mathrm{B}^{\star} 44$, and $\mathrm{B}^{\star} 49$ were in LD with H63D. Altogether, our results show that, although the H63D mutation is more common in the Antioquia population, it is not associated with any particular HLA haplotype, whereas the C282Y mutation is associated with HLA-A*03-B*07, this supporting a northern Spaniard ancestry.
\end{abstract}

Keywords: hereditary hemochromatosis, HLA class I genes, HFE gene, H63D, C282Y.

Received: March 12, 2014; Accepted: August 19, 2014.

\section{Introduction}

Hereditary hemochromatosis (HH, OMIM \#235200) is an autosomal recessive disorder of iron metabolism, characterized by increased iron absorption leading to severe iron deposition and damage of different organs (Janssen and Swinkels, 2009). HH is most often caused by at least two missense mutations in the $H F E$ gene: the c.C187G mutation of exon 2, which results in the substitution of histidine by aspartic acid at amino acid 63 (H63D) and the c.G845A mutation of exon 4, which results in the substitution of cysteine by tyrosine at amino acid 282 (C282Y). The HFE gene is located on the short arm of chromosome $6(6 \mathrm{p} 21.3)$ approximately $4 \mathrm{Mb}$ teloremic to the histocompatibility leukocyte antigen (HLA-A) locus (Feder et al., 1996) and linkage disequilibrium has been demonstrated between particular HLA-A and -B alleles and the HFE mutations. Indeed, $\mathrm{C} 282 \mathrm{Y}$ has been reported to be associated with the HLA-A*3 allele and particularly with the HLA-A*3-B*7 haplotype ("the Celtic ancestral haplotype") (Simon et al., 1987) in different populations

Send correspondence to Carlos Velez-Pardo. Grupo de Neurociencias, Instituto de Investigaciones Médicas, Facultad de Medicina, Universidad de Antioquia, Calle 70 No. 52-21, and Calle 62 No. 52-59, Building 1, Room 412, SIU, Medellín, Colombia. E-mail: calberto.velez@udea.edu.co; cvelezp53@gmail.com.
(Distante et al., 2004; Barton et al., 2005) including the Spanish inhabitants (Pacho et al., 2004). The H63D mutation has been found more frequently in Mediterranean populations associated with the HLA-A*29 allele and HLA-A*29-B*44 haplotype (Porto et al., 1998; Cardoso et al., 2002; Pacho et al., 2004). Therefore, the HLA-A-B and the HFE haplotypes are excellent markers to study the diversity of human population and migratory processes.

We reported the presence of the $\mathrm{C} 282 \mathrm{Y}$ mutation in eight out of $13 \mathrm{HH}$ patients and one patient with the H63D mutation in Antioquia, a northwestern province of Colombia (Avila-Gomez et al., 2008a). Moreover, we also found that the prevalence of $\mathrm{H} 63 \mathrm{D}$ and $\mathrm{C} 282 \mathrm{Y}$ in 1120 voluntary blood donors from the Antioquia region is similar to that reported from regions in central and southern Spain (Avila-Gomez et al., 2008b). The Antioquia region in northwestern Colombia has approximately 5,000,000 inhabitants. This population ("paisa community") was established in the middle of the 16th and/or early 17th century by Spanish and Sephardic Jewish settlers (Carvajal-Carmona et al., 2000) and remained in relative isolation until the late 19th century (Arcos-Burgos and Muenke, 2002). Based on these data, we proposed that the $\mathrm{C} 282 \mathrm{Y}$ and H63D HFE mutations found in Antioquias settlers are probably connected with their Celtic (Soto et al., 2000) and North Afri- 
can (Merryweather-Clarke et al., 2000) ancestry. To test this hypothesis, this study aimed to find the possible ancestral association between HLA alleles, haplotypes with the $H F E$ gene (C282 and H63D) mutations in a sample of presumed $\mathrm{HH}$ individuals and deceased organ donors from the Antioquia population.

\section{Subjects and Methods}

\section{Presumed "HH" individuals and controls}

In this study DNA samples from 18 unrelated individuals with presumed hereditary hemochromatosis ("HH") were studied; 13 of these subjects were HFE genotyped within a previous survey (Avila-Gomez et al., 2008a) and five new individuals were recruited at Hospital San Vicente de Paul (Medellin, Colombia). A written informed consent was obtained from all subjects. The control group was composed of 196 deceased donors for organ transplants in Medellin (Colombia) between 2000 and 2009, whose DNA samples were stored at Laboratory de Inmunología de Transplantes del Grupo de Inmunología e Inmunogenética (GICIG) de la Universidad de Antioquia. These donors were HLA-A,-B,-DRB1 typed by PCR-SSP after a written informed consent was granted by the donors' relatives, according to the Colombian legislation for organ and tissue donation. For the HFE typing, the control samples were selected by proportional stratified random sampling in order to have a number of donors per year that was proportional to the total number of donors studied each year.

\section{Detection of H63D and C282Y mutations by PCR-RFLP}

The H63D (nucleotide change c.187 C $>\mathrm{G}$ ) and C282Y (c.845 G > A) mutations were tested by polymerase chain reaction (PCR) and restriction fragment length polymorphism (RFLP) analysis, using the forward and reverse primers and PCR conditions described by Merryweather-Clarke et al. (1998) and Takeuchi et al. (1997), respectively. For H63D, the amplified fragments were digested with $\mathrm{Mbo}$-I and the $294 \mathrm{bp}$ PCR product of H63D (exon 2) region showed three fragments of 140, 99 and $55 \mathrm{bp}$ in wild type DNA, and only two fragments of 239 and $55 \mathrm{bp}$ in mutant DNA. The PCR product of the $367 \mathrm{bp}$ C282Y (exon 4) region was digested with $R s a$-I and generated fragments of 278 and 89 bp in normal DNA and 249, 89 and 29 bp in mutant DNA. PCR digests were analysed on $2.5 \%$ agarose gels.

\section{HLA - AB typing by PCR-SSP}

DNA samples were extracted by salting out from buffy coats obtained from spleen or EDTA-anti-coagulated blood. The DNA concentration of each sample was adjusted to $150 \mathrm{ng} / \mu \mathrm{L}$ and typing of HLA Class I (A,B) and HLA Class II (DRB) was performed by PCR using the HLA-A+B+DRB Typing Tray Kit produced by the Collab- orative Transplant Study (CTS, University of Heidelberg, Heidelberg, Germany). The PCR conditions used were: initial denaturation at $94^{\circ} \mathrm{C}$ for $2 \mathrm{~min}$, followed by 10 cycles of denaturation at $94^{\circ} \mathrm{C}$ for $15 \mathrm{~s}$ and annealing extension at $65^{\circ} \mathrm{C}$ for $1 \mathrm{~min}$. This was followed by 20 cycles of denaturation at $94{ }^{\circ} \mathrm{C}$ for $15 \mathrm{~s}$, annealing at $61^{\circ} \mathrm{C}$ for $50 \mathrm{~s}$, and a final extension at $72{ }^{\circ} \mathrm{C}$ for $30 \mathrm{~s}$. The amplicons were detected by electrophoresis in $2 \%$ agarose gels stained with ethidium bromide. The allelic assignment was performed by amplification pattern analysis using the classification tables provided by the manufacturer.

\section{Statistical analysis}

Descriptive statistics was used to show the baseline characteristics of the groups studied. Allele and genotype frequencies were estimated using a mere gene counting procedure, and haplotype frequencies were estimated using the ELB (Excoffier-Laval-Balding) algorithm for multilocus genotypic data when the gametic phase is unknown. Linkage disequilibrium (LD) between the alleles was estimated by D and D' values; the significance of the association was tested using an extension of Fisher's exact probability test on contingency tables. To test for departures from the assumption of Hardy-Weinberg equilibrium (HWE), a test analogous to Fisher's exact test was used on a contingency table of observed vs. predicted genotype frequencies using a modified version of the Markov-Chain Random Walk algorithm. Statistical analyses were carried out using Arlequin version 3.0 (Switzerland) and Genepop on the web software.

\section{Results}

\section{Demographical characteristics of control and presumed "HH" individuals}

Of the 18 "HH" subjects screened for HFE mutations, $13(72.2 \%)$ were men and their median age was 54 years (interquartile range 44-64). The control group included 197 deceased organ donors; among them 150 (76.1\%) were men. Their median age was 26 years (interquartile range 20-41 years).

\section{Determination of HLA-A, B frequencies according to HFE mutations}

To determine whether HLA Class I alleles were associated with HFE mutations in the studied population, the "HH" individuals and controls were combined in one group and haplotypes were estimated in three or four loci. Thirty-seven HLA-A*-H63D-C282Y haplotypes were estimated, 18 of which presented a frequency above $1 \%$ and represented $92.6 \%$ of the total frequencies observed. The most frequent HLA-A* alleles associated with the H63D mutation were $A * 02, A * 23$, and $A * 29$, while the HLA*03 allele was the most frequent with the $\mathrm{C} 282 \mathrm{Y}$ mutation (Table 1). For the HLA-B*, H63D, and C282Y loci, 54 
Table 1 - Haplotype frequencies of HLA-A*-H63D-C282Y in unrelated individuals.

\begin{tabular}{lc}
\hline HLA-A*-H63D-C282Y 2n=428 & Frequencies (\%) \\
\hline $02, \mathrm{C}, \mathrm{G}$ & $82(19.2)$ \\
$24, \mathrm{C}, \mathrm{G}$ & $75(17.5)$ \\
$30, \mathrm{C} \mathrm{G}$ & $22(5.1)$ \\
$03, \mathrm{C}, \mathrm{G}$ & $21(4.9)$ \\
$23, \mathrm{C} \mathrm{G}$ & $21(4.9)$ \\
68, C, G & $20(4.7)$ \\
$31, \mathrm{C}, \mathrm{G}$ & $18(4.2)$ \\
$\mathbf{0 2}, \mathbf{G}, \mathbf{G}$ & $\mathbf{1 7}(\mathbf{4 . 0})$ \\
$01, \mathrm{C}, \mathrm{G}$ & $16(3.7)$ \\
$33, \mathrm{C}, \mathrm{G}$ & $16(3.7)$ \\
26, C, G & $16(3.7)$ \\
$11, \mathrm{C}, \mathrm{G}$ & $15(3.5)$ \\
$\mathbf{2 3}, \mathbf{G}, \mathbf{G}$ & $\mathbf{1 3 ( 3 . 0 )}$ \\
$\mathbf{2 9}, \mathbf{G}, \mathbf{G}$ & $\mathbf{1 1}(\mathbf{2 . 6})$ \\
32, C, G & $10(2.3)$ \\
$03, \mathrm{G}, \mathrm{G}$ & $9(2.1)$ \\
$\mathbf{0 3}, \mathbf{C}, \mathbf{A}$ & $\mathbf{8 ( 1 . 9 )}$ \\
29, C, G & $7(1.6)$ \\
\hline
\end{tabular}

HLA-B*-H63D-C282Y haplotypes were estimated, 28 of which presented a frequency above $1 \%$ and represented $87.5 \%$ of the total frequencies observed (Table 2). The most frequent alleles with the H63D mutation were $\mathrm{B} * 44$, $\mathrm{B} * 35$, and $\mathrm{B} * 49$, while the most frequent $\mathrm{B}$ allele associated with the $\mathrm{C} 282 \mathrm{Y}$ mutation was HLA-B*07. Additionally, 173 HLA-A*-B*-H63D-C282Y haplotypes were estimated, 21 of which presented a frequency above $1 \%$ and represented $45.4 \%$ of the total frequencies observed (Table 3). The most frequent HLA haplotypes with mutation in the H63D locus were HLA-A*29-B*44, HLA-A*03-B*35, HLA-A*02-B*44, and HLA-A*23-B*49. The most frequent haplotype with the $\mathrm{C} 282 \mathrm{Y}$ mutation was HLA-A*03-B*07. The HLA-A*29, B*44, and B*49 alleles were in linkage disequilibrium with the H63D mutation $(\mathrm{D}=0.50 ; \mathrm{D}=0.24 ; \mathrm{D}=0.52$, respectively, $\mathrm{p}<$ $0.0001)$. In the same manner, HLA-A*03 $(\mathrm{D}=0.35)$ and HLA-B*07 $(\mathrm{D}=0.38)$ were in linkage disequilibrium with the $\mathrm{C} 282 \mathrm{Y}$ mutation.

\section{Discussion}

The immigration of Spaniards to the Americas was massive in the late 16 th and early 20 th century. This population movement is in accordance with the "demicdiffusion" model (Carvajal-Carmona et al., 2000; Bedoya et al., 2006). Hence, the HLA allele and haplotype and the prevalence of the HFE mutations in the Americas, particularly in Colombia, would be expected to be directly influenced by this migration model. This is the first ancestral
Table 2 - Haplotype frequencies of HLA-B*-H63D-C282Y in unrelated individuals.

\begin{tabular}{|c|c|}
\hline HLA-B*-H63D-C282Y 2n = 428 & Frequencies $(\%)$ \\
\hline $35, \mathrm{C}, \mathrm{G}$ & $78(18.2)$ \\
\hline $44, \mathrm{C}, \mathrm{G}$ & $28(6.5)$ \\
\hline $39, \mathrm{C}, \mathrm{G}$ & $23(5.4)$ \\
\hline $18, \mathrm{C}, \mathrm{G}$ & $23(5.4)$ \\
\hline $51, \mathrm{C}, \mathrm{G}$ & $22(5.1)$ \\
\hline $44, G, G$ & $19(4.4)$ \\
\hline $65, \mathrm{C}, \mathrm{G}$ & $16(3.7)$ \\
\hline $61, \mathrm{C}, \mathrm{G}$ & $15(3.5)$ \\
\hline $07, \mathrm{C}, \mathrm{G}$ & $14(3.3)$ \\
\hline $58, \mathrm{C}, \mathrm{G}$ & $11(2.6)$ \\
\hline $35, \mathbf{G}, \mathbf{G}$ & $11(2.6)$ \\
\hline $38, \mathrm{C}, \mathrm{G}$ & $11(2.6)$ \\
\hline $50, \mathrm{C}, \mathrm{G}$ & $10(2.3)$ \\
\hline $60, \mathrm{C}, \mathrm{G}$ & $9(2.1)$ \\
\hline $49, \mathbf{G}, \mathbf{G}$ & $9(2.1)$ \\
\hline $08, \mathrm{C}, \mathrm{G}$ & $8(1.9)$ \\
\hline $57, \mathrm{C}, \mathrm{G}$ & $7(1.6)$ \\
\hline 07, C, A & $7(1.6)$ \\
\hline $49, \mathrm{C}, \mathrm{G}$ & $6(1.4)$ \\
\hline $63, \mathrm{C}, \mathrm{G}$ & $6(1.4)$ \\
\hline $62, \mathrm{C}, \mathrm{G}$ & $6(1.4)$ \\
\hline $40, \mathrm{C}, \mathrm{G}$ & $5(1.2)$ \\
\hline $53, \mathrm{C}, \mathrm{G}$ & $5(1.2)$ \\
\hline $41, \mathrm{C}, \mathrm{G}$ & $5(1.2)$ \\
\hline $52, \mathrm{C}, \mathrm{G}$ & $5(1.2)$ \\
\hline $72, \mathrm{C}, \mathrm{G}$ & $5(1.2)$ \\
\hline $27, \mathrm{C}, \mathrm{G}$ & $5(1.2)$ \\
\hline $18, \mathrm{G}, \mathrm{G}$ & $5(1.2)$ \\
\hline
\end{tabular}

association study between HLA haplotypes and HFE gene mutations conducted in Colombia, and particularly in the northwestern province of Antioquia. Our results confirm the association between the HLA-A*03-B*07 haplotype and the $\mathrm{C} 282 \mathrm{Y}$ mutation reported in many populations (Barton andActon, 2002; Distante et al., 2004; Pacho et al., 2004; Barton et al., 2005). We also found that the HLA-A*03-B*35 haplotype associated with the H63D mutation is increased in the studied population. Interestingly, the HLA-A*03-B*35 has been linked to hemochromatosis in north-eastern regions of Italy (Panajotopoulos et al., 1989; De Menis et al., 1990), but not so in Spain, where there is a significant association between the HLA-A*03-B*62 and HLA-A*03-B*44 haplotypes and the $\mathrm{C} 282$ Y mutation (Pacho et al., 2004). Since HLA-B*35 is one of the commonest allele (17.8\%) in paisa population (Rodríguez et al., 2007), HLA-A*03-B*35 may represent a distinctive haplotype marker of Antioquia population 
Table 3 - Haplotype frequencies of HLA-A*-B*-H63D-C282Y in unrelated individuals.

\begin{tabular}{lc}
\hline HLA-A*-B*-H63D-C282Y 2n= 428 & Frequencies $(\%)$ \\
\hline $24,35, \mathrm{C}, \mathrm{G}$ & $45(10.5)$ \\
$02,39, \mathrm{C}, \mathrm{G}$ & $16(3.7)$ \\
$02,35, \mathrm{C}, \mathrm{G}$ & $10(2.3)$ \\
$02,44, \mathrm{C}, \mathrm{G}$ & $10(2.3)$ \\
$03,07, \mathrm{C}, \mathrm{G}$ & $9(2.1)$ \\
$33,65, \mathrm{C}, \mathrm{G}$ & $9(2.1)$ \\
$02,18, \mathrm{C}, \mathrm{G}$ & $9(2.1)$ \\
$\mathbf{2 9}, \mathbf{4 4}, \mathbf{G}, \mathbf{G}$ & $\mathbf{8 ( 1 . 9 )}$ \\
$02,51, \mathrm{C}, \mathrm{G}$ & $8(1.9)$ \\
$26,38, \mathrm{C}, \mathrm{G}$ & $8(1.9)$ \\
$\mathbf{0 3}, \mathbf{3 5}, \mathbf{G}, \mathbf{G}$ & $\mathbf{7 ( 1 . 6 )}$ \\
$03,35, \mathrm{C}, \mathrm{G}$ & $6(1.4)$ \\
$68,18, \mathrm{C}, \mathrm{G}$ & $6(1.4)$ \\
$\mathbf{0 2}, \mathbf{4 4}, \mathbf{G}, \mathbf{G}$ & $\mathbf{6 ( 1 . 4 )}$ \\
$\mathbf{2 3}, \mathbf{4 9}, \mathbf{G}, \mathbf{G}$ & $\mathbf{6 ( 1 . 4 )}$ \\
$\mathbf{0 3}, \mathbf{0 7}, \mathbf{C}, \mathbf{A}$ & $\mathbf{6 ( 1 . 4 )}$ \\
$24,61, \mathrm{C}, \mathrm{G}$ & $5(1.2)$ \\
$02,50, \mathrm{C}, \mathrm{G}$ & $5(1.2)$ \\
$24,18, \mathrm{C}, \mathrm{G}$ & $5(1.2)$ \\
$11,35, \mathrm{C}, \mathrm{G}$ & $5(1.2)$ \\
$31,61, \mathrm{C} \mathrm{G}$ & $5(1.2)$ \\
\hline
\end{tabular}

(21.5\%) frequency (Rodríguez et al., 2007). Recently, Olsson et al. (2010) suggested that HLA-A*03-B14 and HLA-A*03-B*07 might be the ancestral haplotypes of the C282Y mutation in a Scandinavian family with major iron overload. Taken together, our data support that the C282Y mutation found in Antioquia might be connected with the Celtic ancestral A*03-B*07 haplotype (Soto et al., 2000).

We have previously proposed that whilst the $\mathrm{C} 282 \mathrm{Y}$ HFE mutation found in Antioquia is probably connected with Celtic ancestry (Pacho et al., 2004), the H63D mutation might be originally connected to a North African population (Merryweather-Clarke et al., 2000). It is generally well accepted that the $\mathrm{C} 282 \mathrm{Y}$ mutation arose from a Celtic ancestry (Lucotte and Dieterlen, 2003; Milman and Pedersen, 2003) some 60 generations ago, before 4000 B.C. (Distante et al., 2004). Consequently, it has been postulated that the gradient distribution of frequencies in hemochromatosis is similar to the Celtic or Viking migration streams in Europe. In Spain, the Celtic invasion initiated in the 9th Century B.C. and lasted until 500 B.C., resulting in a brand new populace known as Celtiberian people (Celts plus native Iberians), which in turn spread from the north to the middle of the Iberian Peninsula (Lorrio and Ruiz-Zapatero, 2005). Accordingly, the northern regions of Spain, such as Galicia, Asturias, Cantabria, and Basque Country present high $\mathrm{C} 282 \mathrm{Y}$ allele frequencies
(3-5\%) similar to the frequencies of Wales (UK) or Toulouse (France) (Merryweather-Clarke et al., 1998). These results have been interpreted as a Celtic legacy by the well-matched high $\mathrm{C} 282 \mathrm{Y}$ frequency, historical records and/or geographical isolation (Soto et al., 2000). Thus, the strong association between the HLA-A*03-B*07 haplotype and the $\mathrm{C} 282 \mathrm{Y}$ mutation found in Antioquia suggests that this mutation is originally connected with Celtic ancestry through the Spaniards' settlement.

Because the origin of the H63D mutation is less certain and because the highest H63D frequency was detected in Spain, Aguilar-Martinez et al. (1999) hypothesized that the H63D mutation emerged in the Iberian Peninsula. Alternatively, the H63D could have arisen in the Middle-East or in Northern Africa. Indeed, H63D is found in countries bordering the Mediterranean, the Middle East, and in the Indian subcontinent (Merryweather-Clarke et al., 2000). Furthermore, the allele frequency of $\mathrm{C} 282 \mathrm{Y}$ is extremely low (0.9-0.09\%) (Sassi et al., 2004; Ezzikouri et al., 2008) or inexistent (Jeffery et al., 1999; Roth et al., 1997; Gunel-Ozcan et al., 2006; Settin et al., 2006) in African countries and Turkey. These data clearly suggest that the C282Y mutation is restricted to Europeans, but the H63D is not. These observations suggest that the H63D mutation may have arisen more than once in geographically distant regions (Rochette et al., 1999) and that this mutation may be older than the C282Y mutation (Distante et al., 2004). Additionally, the H63D allele frequencies found in Spain are similar to the allele frequency reported from the Sephardic Jewish (Matas et al., 2006), Morroquian and Algerian (Aguilar-Martinez et al., 2001; Ezzikouri et al., 2008), Tunisian (Sassi et al., 2004) and Turkish (Simsek et al., 2004) populations. Because Jews traditionally seldom intermarry and no historical records of population movements (invasions or massive migration) exist that could associate Turkish with Spanish people, the conquest of the former Roman province of Hispania by the Moors between 711-1492 A.D. certainly marked the history, culture and most probably the genetic makeup of the Spanish population (Lucotte et al., 2001; Gérard et al., 2006).

Although at present no data is available on the association between HLA haplotype and HFE mutations in African countries, Martinez-Laso et al. (1995) reported that HLA haplotypes in Basques and Spaniards are closer to paleo-North African populations than to other Europeans. Moreover, the fact that Basques, Spaniards and Algerians shared common HLA haplotypes (e.g., A*33-B*14-DR1) and even specific haplotypes (e.g., Basques and Algerians A*11-B*27-DR1 and A*02-B*35-DR11), suggests a relative high admixture with North-Africans (Arnaiz-Villena et al., 1997). Altogether, our results show that, although the H63D mutation is more common in the Antioquia population, it is not associated with any particular HLA haplotype, whereas the $\mathrm{C} 282 \mathrm{Y}$ mutation is associated with 
HLA-A*03, B*07 and supports its presence through the northern Spaniard ancestry.

\section{Acknowledgments}

This study was supported by Colciencias grant \#1115-041-6337 and the project "Estudio enfermedades neurodegenerativas \#8780" of MJ-Del-Rio and CVP; and by "Estrategia de Sostenibilidad, Vicerrectoría de Investigaciones, Universidad de Antioquia" of the Grupo de Inmunología Celullar e Inmunogenética.

\section{References}

Aguilar-Martinez P, Thelcide C, Jeanjean P, Masmejean C, Giansily M and Schved JF (1999) Haplotype analysis of the HFE gene: Implications for the origins of hemochromatosis related mutations. Blood Cells Mol Dis 25:166-169.

Arcos-Burgos M and Muenke M (2002) Genetics of population isolates. Clin Genet 61:233-247.

Aguilar-Martinez P, Picot MC, Becker F, Boulot P, Montoya F, Mares P, Bachelard B, Henry Y, Delarbre JL, Sarda P et al. (2001) Prevalence of HFE mutations in people from North Africa living in southern France. $\mathrm{Br} \mathrm{J}$ Haematol 114:914-916.

Arnaiz-Villena A, Martínez-Laso J, Gómez-Casado E, DíazCampos N, Santos P, Martinho A and Breda-Coimbra H (1997) Relatedness among Basques, Portuguese, Spaniards, and Algerians studied by HLA allelic frequencies and haplotypes. Immunogenetics 47:37-43.

Avila-Gomez IC, Latorre-Sierra G, Restrepo-Gutierrez JC, Correa-Arango G, Jimenez-Del-Rio $\mathrm{M}$ and Velez-Pardo $\mathrm{C}$ (2008a) Analysis of the HFE gene (H63D and C282Y) mutations in patients with iron overload, family members and controls from Antioquia, Northwest Colombia. Clin Genet 73:92-93.

Avila-Gomez IC, Aristizabal-Bernal B, Jimenez-Del-Rio M and Velez-Pardo C (2008b) Prevalence of H63D, S65C and $\mathrm{C} 282 \mathrm{Y}$ mutations of the $H F E$ gene in 1120 voluntary blood donors in northwest Colombia. Blood Cells Mol Dis 40:449-451.

Barton JC and Acton RT (2002) HLA-A and -B alleles and haplotypes in hemochromatosis probands with HFE C282Y homozygosity in central Alabama. BMC Med Genet 3:e9.

Barton JC, Wiener HW, Acton RT and Go RC (2005) HLA haplotype $\mathrm{A}^{*} 03-\mathrm{B} * 07$ in hemochromatosis probands with HFE C282Y homozygosity: Frequency disparity in men and women and lack of association with severity of iron overload. Blood Cells Mol Dis 34:38-47.

Bedoya G, Montoya P, García J, Soto I, Bourgeois S, Carvajal L, Labuda D, Alvarez V, Ospina J, Hedrick PW et al. (2006) Admixture dynamics in Hispanics: A shift in the nuclear genetic ancestry of a South American population isolate. Proc Natl Acad Sci USA 103:7234-7239.

Bengtsson BO and Thomson G (1981) Measuring the strength of associations between HLA antigens and diseases. Tissue Antigens 18:356-363.

Cardoso CS, Alves H, Mascarenhas M, Gonçalves R, Oliveira P, Rodrigues P, Cruz E, de Sousa M and Porto G (2002) Co-selection of the H63D mutation and the HLA-A29 allele:
A new paradigm of linkage disequilibrium? Immunogenetics 53:1002-1008.

Carvajal-Carmona LG, Soto ID, Pineda-Trujillo N, Ortíz-Barrientos D, Duque C, Ospina-Duque J, McCarthy M, Montoya P, Alvarez VM, Bedoya G et al. (2000) Strong Amerind/white sex bias and a possible Sephardic contribution among the founders of a population in northwest Colombia. Am J Hum Genet 67:1287-1295.

De Menis E, Breda F, Monco A, Foscolo G, Legovini P, Scaldaferri E, Moro L and Conte N (1990) HLA antigens and haplotypes associated with idiopathic haemochromatosis in Veneto: Peculiar association with HLA-A3,B35. Acta Haematol 83:113-115.

Distante S, Robson KJ, Graham-Campbell J, Arnaiz-Villena A, Brissot P and Worwood M (2004) The origin and spread of the HFE-C282Y haemochromatosis mutation. Hum Genet 115:269-279.

Ezzikouri S, El Feydi AE, El Kihal L, Afifi R, Benazzouz M, Hassar M, Chafik A, Pineau P and Benjelloun S (2008) Prevalence of common HFE and SERPINA1 mutations in patients with hepatocellular carcinoma in a Moroccan population Arch Med Res 39:236-341.

Feder JN, Gnirke A, Thomas W, Tsuchihashi Z, Ruddy DA, Basava A, Dormishian F, Domingo Jr R, Ellis MC, Fullan A et al. (1996) A novel MHC class I-like gene is mutated in patients with hereditary haemochromatosis. Nat Genet 13:399-408.

Gérard N, Berriche S, Aouizérate A, Diéterlen F and Lucotte G (2006) North African Berber and Arab influences in the western Mediterranean revealed by Y-chromosome DNA haplotypes. Hum Biol 78:307-316.

Gunel-Ozcan A, Alyilmaz-Bekmez S, Guler EN and Guc D (2006) HFE H63D mutation frequency shows an increase in Turkish women with breast cancer. BMC Cancer 6:e37.

Janssen MC and Swinkels DW (2009) Hereditary haemochromatosis Best Pract Res Clin Gastroenterol 23:171-183.

Jeffery S, Crosby A, Plange-Rhule J, Amoah-Danquah J, Acheampong JW, Eastwood JB and Malik AK (1999) Evidence from a Ghanaian population of known African descent to support the proposition that hemochromatosis is a Caucasian disorder. Genet Test 3:375-377.

Lorrio AJ and Ruiz-Zapatero G (2005) Celts in Iberia: An overview. J Interdisc Celtic Stud (e-Keltoi) 6:167-254.

Lucotte G and Dieterlen F (2003) A European allele map of the C282Y mutation of hemochromatosis: Celtic vs. Viking origin of the mutation? Blood Cells Mol Dis 31:262-267.

Lucotte G, Gérard N and Mercier G (2001) North African genes in Iberia studied by Y-chromosome DNA haplotype 5. Hum Biol 73:763-769.

Martinez-Laso J, De Juan D, Martinez-Quiles N, Gomez-Casado E, Cuadrado E and Arnaiz-Villena A (1995) The contribution of the HLA-A, -B, -C and -DR, -DQ DNA typing to the study of the origins of Spaniards and Basques. Tissue Antigens 45:237-245.

Matas M, Guix P, Castro JA, Parera M, Ramon MM, Obrador A and Picornell A (2006) Prevalence of HFE C282Y and H63D in Jewish populations and clinical implications of H63D homozygosity. Clin Genet 69:155-162.

Merryweather-Clarke AT, Shearman JD, Robson KJ, Pointon JJ, Liu YT, Bomford A, Dooley J, Walker AP and Worwood M 
(1998) Hemochromatosis-related mutation detection. Blood 91:2620-2621.

Merryweather-Clarke AT, Pointon JJ, Jouanolle AM, Rochette J and Robson KJ (2000) Geography of HFE C282Y and H63D mutations. Genet Test 4:183-198.

Milman N and Pedersen P (2003) Evidence that the Cys282Tyr mutation of the HFE gene originated from a population in Southern Scandinavia and spread with the Vikings. Clin Genet 64:36-47.

Olsson KS, Ritter B and Raha-Chowdhury R (2010) HLA-A3-B14 and the origin of the haemochromatosis C282Y mutation: Founder effects and recombination events during 12 generations in a Scandinavian family with major iron overload. Eur J Haematol 84:145-153.

Pacho A, Mancebo E, del Rey MJ, Castro MJ, Oliver D, García-Berciano M, González L and Morales P (2004) HLA haplotypes associated with hemochromatosis mutations in the Spanish population. BMC Med Genet 5:e25.

Panajotopoulos N, Piperno A, Conte D, Mandelli C, Cesana M, Mercuriali F, Fiorelli G, Bianchi PA and Fargion S (1989) HLA typing in 67 Italian patients with idiopathic hemochromatosis and their relatives. Tissue Antigens 33:431-436.

Porto G, Alves H, Rodrigues P, Cabeda JM, Portal C, Ruivo A, Justiça B, Wolff R and De Sousa M (1998) Major histocompatibility complex class I associations in iron overload: Evidence for a new link between the HFE H63D mutation, HLA-A29, and non-classical forms of hemochromatosis. Immunogenetics 47:404-410.

Rochette J, Pointon JJ, Fisher CA, Perera G, Arambepola M, Arichchi DS, De Silva S, Vandwalle JL, Monti JP, Old JM et al. (1999) Multicentric origin of hemochromatosis gene (HFE) mutations. Am J Hum Genet 64:1056-1062.

Rodríguez LM, Giraldo MC, García N, Velásquez L, París SC, Alvarez CM and García LF (2007) Human leucocyte antigen gene (HLA-A, HLA-B, HLA-DRB1) frequencies in deceased organ donors. Biomedica 27:537-547.

Roth M, Giraldo P, Hariti G, Poloni ES, Sanchez-Mazas A, Stefano GF, Dugoujon JM and Coppin H (1997) Absence of the hemochromatosis gene Cys282Tyr mutation in three ethnic groups from Algeria (Mzab), Ethiopia, and Senegal. Immunogenetics 46:222-225.

Sassi R, Hmida S, Kaabi H, Hajjej A, Abid A, Abdelkefi S, Yacoub S, Maamar M, Mojaat N, Ben Hamed L et al. (2004) Prevalence of $\mathrm{C} 282 \mathrm{Y}$ and $\mathrm{H} 63 \mathrm{D}$ mutations in the haemochromatosis (HFE) gene in Tunisian population. Ann Genet 47:325-330.

Settin A, El-Bendary M, Abo-Al-Kassem R and El Baz R (2006) Molecular analysis of A1AT (S and Z) and HFE (C282Y and H63D) gene mutations in Egyptian cases with HCV liver cirrhosis. J Gastrointestin Liver Dis 15:131-135.

Simon M, Le Mignon L, Fauchet R, Yaouanq J, David V, Edan G and Bourel M (1987) A study of 609 HLA haplotypes marking for the hemochromatosis gene: (1) mapping of the gene near the HLA-A locus and characters required to define a heterozygous population and (2) hypothesis concerning the underlying cause of hemochromatosis-HLA association. Am J Hum Genet 41:89-105.

Simsek H, Sumer H, Yilmaz E, Balaban YH, Ozcebe O, Hascelik G, Buyukask Y and Tatar G (2004) Frequency of HFE mutations among Turkish blood donors according to transferrin saturation: Genotype screening for hereditary hemochromatosis among voluntary blood donors in Turkey. J Clin Gastroenterol 38:671-675.

Soto L, Vega A, Goyanes V and Valverde D (2000) Hemochromatosis in Galicia (nw Spain): A Celtic influence? Clin Genet 57:454-455.

Takeuchi T, Soejima H, Faed JM and Yun K (1997) Efficient large-scale screening for the hemochromatosis susceptibility gene mutation. Blood 90:2848-2849.

\section{Internet Resources}

Genepop, http://genepop.curtin.edu.au (accessed on July 14, 2014).

Associate Editor: Maria Luiza Petzl-Erler

License information: This is an open-access article distributed under the terms of the Creative Commons Attribution License, which permits unrestricted use, distribution, and reproduction in any medium, provided the original work is properly cited. 